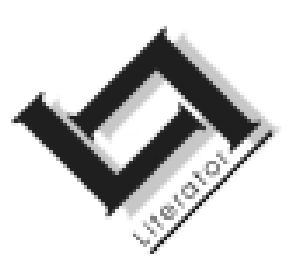

\title{
Van kind tot jong volwassene: Die ontwikkeling van die hoofkarakter in De koperen tuin van Simon Vestdijk ${ }^{1}$
}

\author{
Betsie van der Westhuizen \\ Vakgroep Afrikaans en Nederlands \\ Potchefstroomse Universiteit vir $\mathrm{CHO}$ \\ POTCHEFSTROOM \\ E-pos: afnesvdw
}

\section{Abstract}

From child to young adult: The development of the main character in De koperen tuin (The garden where the brass band played) by Simon Vestdijk

From an intertextual study it emerges that the postulated view of reality in the psychological-philosophical text De toekomst der religie (The future of religion) (1947) is transposed in narrative form in the text-internal vision of reality in the novel De koperen tuin (The garden where the brass band played) (1950). In both these texts the religious point of departure of the meaning of existence is reflected upon. Existential aspects especially highlighted, include the following: the I, the relationship with others, being involved in the situation, freedom, responsibility, guilt, angst, death, that which is "too-late". Furthermore the extension of the moment, the directedness at a personal passion, and the individual's courage to be and to keep "becoming" are also highlighted. All these aspects emphasizing existentialism are portrayed in the development of the main character, Nol Rieske, from little boy to young adult.

$1 \quad$ Hierdie artikel is gebaseer op 'n M.A.-verhandeling (De toekomst der religie en De koperen tuin van Simon Vestdijk: 'n intertekstuele ondersoek) wat in 1990 voltooi is onder die studieleiding van prof. Jacques van der Elst. 


\section{Inleidend}

Vanaf die dertiger- tot die tagtigerjare het die werk van Simon Vestdijk 'n baie prominente rol gespeel in die Nederlandse literêre lewe, maar dit het as gevolg van die nuuswaardigheid van nuwe skrywers tydelik ietwat op die agtergrond geraak tydens die negentigerjare. Daar is tans weer 'n hernieude belangstelling in sy literêr-artistieke werk, en veral sy poësie word druk gelees. Tog bly sy prosa belangrik en navorsingswaardig. Op die Schrijversnet-webtuiste (2001.02.05) waar Vestdijk sy plek het as een van die Nederlandse letterkunde se grootstes, word die volgende romans uitgelig as deel van die Nederlandse "Twentieth Century Classics": Terug tot Ina Daman (1934), Meneer Visser's hellevaart (1936), De kellner en de levenden (1949) en De koperen tuin (1950). Op dieselfde webtuiste word daar soos volg oor De koperen tuin aangehaal uit 'n resensie van Tim Gooderham in The Times Literary Supplement (s.j.):

... in numerous novels Vestdijk gave lasting shape to that period of transition known as youth. For many, including the author himself, the novel The garden where the brass band played is the pinnacle achievement in this field. The density and variety of The garden where the brass band played make it a difficult but rewarding book; its thematic complexity is underpinned by a series of recurring images which take on deeper significance as the mood grows darker. It is an achievement to be placed somewhere between Thomas Hardy and Thomas Mann.

By die lees van sowel sy poësie as prosa val dit op dat die lewensbeskoulike aspekte van sy skrywerskap besonder prominent is. Tog is daar sekere immergroen werke, soos die roman De koperen tuin, wat nie net uitstaan in die oeuvre nie, maar wat ook sleutelkodes - vir die doel van hierdie artikel: lewensbeskoulike kodes - verskaf vir die res van sy oeuvre.

Simon Vestdijk, wat steeds allerweë veral deur diegene wat werk met 'n diachroniese benadering tot die Nederlandse letterkunde, beskou word as ' $n$ meesterlike romansier met 'n hoogs ontwikkelde intellek en individualisme, het in 1964 'n eredoktorsgraad van die Rijksuniversiteit te Groningen ontvang, onder andere op grond van sy "oorspronklijke visie op het leven" (Cornets-de Groot, 1972:90).

Hierdie "visie op het leven" toon op baie duidelike wyse 'n intertekstuele samehang in twee sleutelwerke in Vestdijk se oeuvre: die psigologiesfilosofiese werk De toekomst der religie (1947) wat slegs drie jaar vóór die roman De koperen tuin (1950) gepubliseer is. Faber (1980:33) meen meer as dertig jaar na die eerste publikasie van De toekomst der religie 
dat Vestdijk se lewensbeskouing soos dit hierin tot uitdrukking kom, nog lank aktueel sal bly vanweë die "uiters originele verbinding van het thema van de Eeuwige Mens met de vroege kindertijd van de individuele mens, via het projectie-mechanisme", en evalueer dié werk besonder positief: "Het behoort mijns inziens tot de werkelijk grote visies die de Europese cultuur heeft voortgebracht" (Faber, 1980:13).

Wat De koperen tuin betref: dit is die roman (naas De ziener) wat Vestdijk persoonlik as sy heel beste beskou het. Dit is ook 'n roman wat sedert die eerste publikasie daarvan ' $n$ aanhoudende stroom resensies en artikels in literêre tydskrifte ontlok het. Dié roman het dus 'n besonder hoë status in Vestdijk se oeuvre.

Samevattend gestel, gaan die roman oor die retrospeksie van 'n volwasse Nol Rieske wat vertel van sy lewe vanaf sy kleinkinderjare, later kindertyd, sy adolessensie tot met sy jare as mediese student. Talle karakters word gebruik om aan die gesin waaruit Nol kom en aan die samelewing van die stad W... 'n effek van geloofwaardigheid te gee. Die twee belangrikste karakters naas Nol is die musiekonderwyser Henri Cuperus, wat ongeveer teen die helfte van die roman sterf aan alkoholmisbruik, en sy dogter Trix, wat Nol reeds ontmoet het toe hy 'n klein seuntjie was, en met wie hy 'n liefdesverhouding vanaf sy studentetyd het. Die tweede deel van die roman gaan veral om Trix se selfmoord, Nol se geleidelike ontdekking van die moontlike redes daaragter en sy voornemens om sy nuutgevonde visie op die lewe daadwerklik uit te leef.

\section{Teoretiese standpuntinname}

Om 'n literêr-teoretiese onderskeid te tref tussen die lewens- en wêreldbeskouing van die reële outeur en die lewens- en wêreldbeskouing soos dit in 'n roman gerepresenteer is, bly die terme werklikheidsbeskouing van die reële outeur en die visie in die roman soos deur Steenberg (1975) beredeneer, steeds nuttig. Volgens sy uiteensetting is die visie in 'n roman nie teksekstern nie - dit is die beliggaming van die epiestegniese, 'n literêr gekonkretiseerde gegewe wat transformasioneel van die reële outeur verwyder is (Minnaar, 1982:139; Steenberg, 1975:184). Die transformasie is die omsetting van die materiaal uit die reële werklikheid tot romanwerklikheid deur die woord en simbool. Die roman as sodanig is dan 'n visionêre ${ }^{2}$, dinamiese proses en die oordrag van die visie is die teksinterne, dinamiese wisselwerking van verhaalelemente

2 Die spelling van die byvoeglike naamwoord wat saamhang met die selfstandige naamwoord visie is visionêre en nie visioenêre nie (laasgenoemde verwys na visioen, wat glad nie ter sprake is in hierdie artikel nie.) 
vanaf die abstrakte rol van die implisiete outeur as beherende organisasieprinsipe tot die uiteindelike standpunt wat die verhaal as geheel inneem.

Steenberg (1975:207) beskou die ombouing van ervaringsmateriaal (in casu die talige neerslag van die ervaringswerklikheid van die outeur Vestdijk in sy teks De toekomst der religie tot roman, in casu De koperen tuin) as 'n omsettingstransformasie of 'n permutasie waarin die ervaringsmateriaal volgens die eis van die visionêre konsep geselekteer en georden is. Hy verduidelik voorts dat die transformasie van die epiese basis tot oppervlakteverhaal gepaard gaan met verbesondering deur elemente soos karakter, tydruimte en gebeure, en voeg daaraan toe dat die visionêre en die epies-tegniese komponente dán in 'n roman kan bestaan as hulle tot taal getransformeer is deur die verbale komponent (Steenberg, 1975:209).

In De toekomst der religie word dit eksplisiet beklemtoon dat die bevindinge en standpunte van 'n kritikus, al sou hy daarna streef om objektief te werk te gaan, subjektief bepaald is omdat dit ten nouste saamhang met sy eie oortuigings (Vestdijk, 1975:8). In die bepaal van die intertekstuele verhouding tussen De toekomst der religie en $D e$ koperen tuin sal die kritikus as leser se voorveronderstellings uiteraard 'n rol speel in die insien van intertekstuele verbande. Alhoewel die leser 'n verwagtingshorison gebou op intertekstuele kennis en oortuigings meeneem by die interpretasie van die roman, moet deurgaans in die immanente kritiek aangetoon word dat die roman sy eie individuele en unieke diskoers het waaruit die visie uiteindelik tot stand kom, en dat die visie in die roman nie blote sitate uit De toekomst der religie is nie. Sekere uitsprake in die roman sal dus onvermydelik vir die leser 'n verband toon met romaneksterne gegewens, soos Vestdijk se musiekestetika en sy religieuse beskouing. In sy essay getitel De beeldende filosoof oor die filosofiese en literêre werk van Bergson kan ook Vestdijk (1958:156-169) se eie werkwyse afgelei word met betrekking tot die integreer van filosofiese redenasies oor aspekte van 'n eie werklikheidsbeskouing. Behalwe dat die visie geobjektiveer moet word deur onder andere die karakters as deel van die totaliteit van die verhaalwerklikheid, moet daar ook "liefdevolle aandacht voor het concrete detail" (Vestdijk, 1958:169) wees. Hierdie "aandacht voor het concrete detail" is 'n opmerking met belangrike implikasies vir die transponering van die werklikheidsbeskouing in De toekomst der religie tot die visionêre proses in $D e$ koperen tuin - die verskillende verhaalelemente as paradigmas permuteer weer tot in die fynste konkrete besonderhede, tot in die enkele woord en klank. Op dié wyse word daar nie in breë trekke gestaltes geskep wat mymer en filosofeer oor die teksinterne visie nie, maar word 
die talle aspekte van die totaliteit van die werklikheidsvisie in die romanwêreld verbesonder, geobjektiveer en gekonkretiseer, onder andere in die karakterbeelding.

\section{Karakterisering}

\subsection{Die objektivering van idees in karaktergestaltes}

In die transponering van die werklikheidsbeskouing in De toekomst der religie tot werklikheidsbeskouing in De koperen tuin vervul die karakters 'n objektiverende funksie. Die karakterisering is dus enersyds 'n poging van die reële outeur van De toekomst der religie en De koperen tuin om sy werklikheidsbeskoulike standpunte tot gestalte te maak, te konkretiseer. Die karakterisering is andersyds ook 'n poging van die reële outeur om hom te distansieer van sy subjektiewe, eie ek. Uit die visionêre proses in die roman blyk dit dat die ek juis weer (paradoksaal), soos die mistiek-introspektiewe tipe (soos uiteengesit in hoofstuk 5 van De toekomst der religie), soek na sy geïntegreerde self. Die hoofkarakter in die roman kan egter nie sin in sigself vind nie, omdat hy sy self slegs kan vind in 'n sinvolle betrokkenheid by die ander, dit wil sê die medekarakters, in 'n reeks wisselende en dinamiese verhoudinge. Net soos wat daar in De toekomst der religie 'n persoonlikheidstipologie gegee word waarin daar ook besliste standpunt ingeneem word vir of teen bepaalde tipes, so is daar ook in De koperen tuin verskillende karakters wat draers is van verskillende waardes in die roman. Bepaalde karaktertipes (waarmee nie net 'n onderskeid tussen hoof- en medekarakters bedoel word nie, maar ook 'n tipering van karakter- en persoonlikheidseienskappe) in De koperen tuin is dus terselfdertyd sinspelings op en uitbreidings of kondensasies van die persoonlikheidstipes in $D e$ toekomst der religie - die metafisies-projekterende tipe (Vestdijk, 1975:6295), die sosiale tipe (Vestdijk, 1975:96-132) en die mistiek-introspektiewe tipe (Vestdijk, 1975:133-169). Alles wat dan vervolgens onder karakterisering in De koperen tuin ter sprake kom, het betrekking op die intertekstuele verhouding van transformasionele verwerwing van bepaalde positiewe waardes en verwerping van negatiewe waardes met betrekking tot die persoonlikheidstipologie in De toekomst der religie.

\subsection{Nol as hoofkarakter}

Intertekstueel beskou, is Nol as karakter in De koperen tuin 'n objektivering en uitgebreide verbesondering van die kombinasie van die sosiale en die mistiek-introspektiewe tipes (by albei kom positiewe én negatiewe eienskappe voor). Sinspelings op die sosiale tipe in De toekomst der religie kom veral voor in hoofstuk 4 (Vestdijk, 1975:96-132) en sinspelings op die mistiek-introspektiewe tipe in hoofstuk 5 (Vestdijk, 1975: 
133-169); die kombinasie van die eienskappe van hierdie twee tipes word beredeneer in hoofstuk 8 (Vestdijk, 1975:247-248, 267) en hoofstuk 9 (Vestdijk, 1975:281, 309). In die volgende bespreking van die karakterisering van Nol as draer van die visie van die roman word hierdie intertekstuele verbande aangetoon.

Wanneer Nol as eksterne ek-verteller verwys na "deze memoires" (p. 145), maar terselfdertyd ook 'n belewende interne fokalisator in die vertelling is, kan hy steeds subjek van die vertelling bly. Maar wanneer hierdie woorde nadruklik die visie op die eie belewing van die hoofkarakter weergee, is dit volgens Pop (1976:38) "een hachelijke onderneming om het instrument waarmee alle gebeurtenissen en personen zijn waargenomen, eveneens tot object van waarneming te maken en naast de andere personages te plaatsen". Op hierdie probleem het Musarra (1983:99) die antwoord:

De ik-figuur kan niet meer als een van de verteller losstaand en gereconstrueerd object gezien worden, maar veeleer als een tweede subject, waarmee het eerste subject, de ik-verteller, probeert zich te identifiseren.

Hieruit blyk dat die ek-figuur of -karakter één word met die ek-verteller en dus ook via die ek-verteller deur die implisiete outeur gebruik word as draer van die visie, as verhaalelement dus aangewend word in die prosesmatige objektivering van die werklikheidsbeskouing in De toekomst der religie tot visie in die roman De koperen tuin.

Nie alle kritici is dit eens dat Nol Rieske die hoofkarakter van die roman is nie; Oversteegen (1974:59-60) haal onder andere Van der Woude, Gomperts en Van Eckeren in hierdie verband aan. Ook Van Hattum (1977:35-41) beskou Nol nie as die hoofkarakter nie. Ander kritici, soos Bordewijk, met wie Oversteegen dit eens is, noem Nol, Trix en Cuperus as die belangrikste karakters "waarbij de volgorde toch niet irrelevant zal zijn" (Oversteegen, 1974:60). Nol is die vol karakter by wie daar onwikkeling plaasvind; van klein seuntjie tot gelouterde volwasse jong man by wie daar ingrypende lewensinsigte gekom het - hy kan as die hoofkarakter beskou word omdat hy die verteenwoordiger word van al die positiewe waardes van die werklikheidsbeskouing in De toekomst der religie én De koperen tuin. Hy is weliswaar nie deur die loop van die verhaal die held nie - daarvoor het hy té veel gebreke; hy is eerder 'n buitestander wat die gebeure waarneem en deurmaak, sodat die leser déúr hom en deur sy groei gemanipuleer kan word tot instemming met die visie van die verhaal. Hy is dus die geobjektiveerde draer van die totale visie in De koperen tuin, wat weer terugslaan op die werklikheidsbeskouing in De toekomst der religie. 
Die klem op die strewe na die totaliteit van die eienskappe van die volmaakte mens in De toekomst der religie behels ook dat die mens hom moet losmaak van die beeld van die kind. Hy moet hom dus losmaak van die ouerbinding omdat hy volwasse en selfstandig moet word (Vestdijk, 1975:54-58). Die implikasie hiervan vir die transponering van hierdie aspek van die werklikheidsbeskouing in De toekomst der religie tot werklikheidsvisie in De koperen tuin, het op baie vernuftige wyse tot stand gekom in die objektivering van Nol as ontwikkelende karakter. Sy ontwikkeling van klein seuntjie word op die voet gevolg tot en met sy vroeë volwassenheid, waarin hy as jong man met begrip en groter insig kan terugkyk op die pad van sy ontwikkeling. Die hoofmomente in die ontwikkelingsgang van $\mathrm{Nol}$ as hoofkarakter is dus ' $n$ intertekstuele polifonie van sinspelings op een van die aspekte van die werklikheidsbeskouing in De toekomst der religie.

Van sy jonger self as "zoontje van de rechter" (p. 9) berig Nol dat hy gesteld was op sy waardigheid en dat hy uitgemunt het in onuitgelokte geweldpleging op swakker seuntjies, in die stille hoop dat Chris, sy ouer broer wat selde geveg het, hom by die skool sou raaksien. Pop (1976: 38) beweer tereg dat $\mathrm{Nol}$ as klein seuntjie duidelik gely het onder die ouer Chris se magsvertoon wat uit jaloesie voortgespruit het. Hierdie (volgens Pop "natuurlijke") vyandskap tussen die twee het waarskynlik ook ontstaan uit hulle verskillende geaardhede: Chris lyk meer na die verstandelike tipe (dit blyk uit sy "pepermuntstatistieken" - p. 42), terwyl Nol meer kunssinnig is (dis hý wat hom verdiep het in sprokiesboeke en later in musiek).

Aan sefvertroue het dit Nol ook nie ontbreek nie, want wanneer hy in die Tuin halfhartig deur die parkopsigter verbied en daarna tog op 'n ongeoorloofde plek toegelaat is, "straalde het zoontje van de rechter een zeker fluïdum uit” (p. 20-21).

Die gevoelswêreld van die seunsjare is belangrik; dit word duidelik dat dié tyd in Nol se lewe gekompliseerd en vol onwelgevallighede is (Beets, 1977a:5, 15). Namate hy ouer word, word daar onbewus afskeid geneem van die behoefte om 'n oorwinnende rol in seunsgroepe te speel - daar kom dus afskeid van die kollektiewe, daar vind 'n verinnerliking in vriendskappe en verdere isolasie plaas (Beets, 1977a:17-18). In die uitbeelding van die ontwikkeling van 'n klein seuntjie tot jong man het Vestdijk, volgens Beets (1977b:20), veel beter voorgestel wat die psigologiese ontwikkeling van die kind kan inhou as wat in baie wetenskaplike verhandelinge oor die ontwikkelingpsigologie gevind kan word.

Nol se inwyding en ontwikkeling in die musiek was te danke aan sy moeder, want nadat hy saam met haar en haar vriendinne vir die eerste 
keer in die Tuin na Cuperus se musiek gaan luister het - musiek wat hom "een soort getintel in (zijn) benen" (p. 38) laat voel het - het hy by háár aangedring om hom klavierlesse by Cuperus te laat neem. Nol se verering vir Cuperus as dirigent begin tydens hierdie konsert in die Tuin: hy beskou Cuperus as "zonder twijfel de grootste man van W..." (p. 22). In die roman is geen blyke dat Nol se vader met sy musiekbelangstelling bemoeienis gemaak het nie. Trouens, sedert die aanvang van sy klavierlesse het Cuperus as plaasvervangende "vader" Nol se lewe oorheers, deurdat Nol al sy kwellinge as kind aan Cuperus, "de man die ik meer vereerde dan iets ter wereld" (p. 56), toevertrou: "ik vertelde alles over Chris, mijn vroegere kwellingen, en die ene rotsonatine, waar ik altijd zo zenuwagtig van werd, en zelfs de bloedneus haalde ik erbij, en het manke meisje en de sonate van Haydn" (p. 56). Dat Nol daarop aangedring het dat Cuperus hom op sy naam moet noem, dui op 'n gevoelsmatige behoefte. Later het Cuperus tog vir Nol as "Mijn zoon" (p. 104, 143) aangespreek. Nol gedy ook onder Cuperus se komplimente, want al het Cuperus hom dit per slot van sake geleer, was hy soms noukeuriger ten opsigte van musikale detail as Cuperus, en "nooit heb ik zo fel gebloosd als door zijn mededeling dat ik meer als een vakman luisterde dan hij" (p. 84).

Nol erken ook ronduit dat Cuperus 'n enorme invloed op hom verkry het, want "ik liep zoals hij liep, een beetje militair; ik probeerde te loensen zonder te loensen; ik probeerde sigaren te roken, met heilloos gevolg" (p. 82). Maar die nagevolge van die sigaarrook sou nie die enigste "heilloos gevolg" wees nie; volgens Pop (1976:39) is "het dienen van een idool ... een excuus voor het minder goed functioneren met de eigen omgeving", omdat daar behalwe Cuperus uiteindelik niemand anders is met wie hy gedagtes en ervaringe kan deel op die gebied wat hom die diepste raak nie - dié van die musiek en vanselfsprekend later ook die liefde. Ná Cuperus en Vellinga se ontmoeting in die gang van Nol-hulle se huis, het Nol gedink: "Voor mijn gevoel was Cuperus tegelijk iets gestegen en iets gedaald" (p. 55) en 'n paar maande later voel hy ook dat "het zoenen van het dienstmeisje ... hem ook in mijn achting doen dalen (had)" (p. 63). Nogtans bly Nol se verering vir Cuperus so groot dat hy, nadat hy die geld van die fondsinsameling aan Cuperus oorhandig het, homself daaraan herinner dat "doordat ik zijn weldoener geworden was, voelde ik mij des te meer verplicht mijn ziel ondergeschikt te maken aan de zijne" (p. 82).

Tydens sowel die inoefening as die opvoering van Carmen was Nol voortdurend getuie van Cuperus se absolute inlewing in die Carmenmusiek, sodat Nol se liefde vir musiek en sy verering vir sy leermeester empatie met Cuperus vanselfsprekend gemaak het. Omdat die orkes 
swak gespeel het en die gehoor hulle misnoeë luidkeels laat blyk het, "genoot ik niet meer; ik was bang ter wille van Cuperus" (p. 126). Pop (1976:40) wys daarop dat Nol later Cuperus se vernedering op een lyn geplaas het met sy eie (en Trix se) ervaring:

Een schouwburgzaal tegen een bulderende en huilende Cuperus, tegen wie niemand in het bijzonder iets had, afgezien van een infantiele behanger en stoffeerder. Een bende jongens tegen een schoppende Trix. Een bende schreeuwende jongens tegen een kleine 'rot-Nol' op een balcon (p. 236).

In die verloop van die verhaal word Nol groot en op negentien was hy 'n blosende, gesonde en breedgeskouerde jong man. Belangriker as die fisiese ontwikkeling is dat hy ten opsigte van sy karakterontwikkeling op die stadium van Cuperus se dood homself nog steeds beskoulik gedistansieer het van die gemeenskap. Hy was 'n onbetrokke individualis, want hy hoor gesprekke aan "met de gemoedsrust van een stoicyn" (p. 169), omdat dit hom nie kan skeel of die gemeenskap Cuperus se nagedagtenis verneder nie: "men mocht hem belasteren, men mocht zijn talent betwijfelen, men mocht hem de mislukking van de Carmen in de schoenen schuiven, men mocht zijn lijk opgraven en in mootjes snijden, het raakte mij niet" (p. 169). Vir Nol is Cuperus onaantasbaar. Alhoewel hy Cuperus se dood so smartlik ervaar het - "het verdriet kwam uit mijn ingewanden op als een bol lauw vuur, en ik moest in mijn kussen bijten om het niet uit te schreeuwen" (p. 166) - is hier dus nog geen sprake van sosiale bewuswording en 'n besef van die verantwoordelikheid van die self om betrokke te raak hy die lot van die medemens nie. Hy leef dus nog egosentries.

Tog is hier duidelike blyke dat Nol Cuperus as slagoffer van die gemeenskap sien - slagoffer van die magte in homself, naamlik sy dranksug, maar ook van magte búite homself, by name die koel onverdraagsaamheid van die sogenaamd beskaafde gemeenskap. Al was dit dan reeds te laat, sou eers 'n gebeurtenis so skokkend-ingrypend soos Trix se selfmoord Nol kon beweeg om verantwoordlikheid op homself te neem met betrekking tot meelewing met ander.

In Nol se karakterontwikkeling is dit funksioneel dat die twee belangrikste medekarakters albei in die eksposisie van die verhaal bekendgestel word. Cuperus begelei Nol bewus en onbewus (maar nooit letterlik nie) as vaderfiguur in sy ontwikkeling as jong seun en tiener in die eerste helfte van die verhaal, terwyl Trix as sy geliefde hom in die tweede helfte onbewus deur haar sterwe lei tot die afsterf van sy egosentriese self. Sodoende word hy as volwasse jong man bewus van sy verantwoordelikheid om persoonlik sin te gee aan sy bestaan. Die geleidelike 
óórgang in die struktureel-funksionele rol wat Cuperus en Trix speel in die karakterontwikkeling van Nol, vind dan plaas in die tydperk rondom die Carmen-opvoering en Cuperus se dood.

Waar daar voorheen konflik was tussen Nol en sy moeder oor Cuperus as musiekonderwyser en as mens, sit hy hierdie verdediging van die verontregte medemens voort met sy moeder wanneer sy Nol konfronteer met die subtiele kritiek op "dat aardige Trixje van je" (p. 146). Hierdie aanmerking wil Nol wreek deur sy moeder onder ewe subtiele, maar tog meedoënlose kruisverhoor te neem oor Vellinga en die ander mans. Sy verhouding met sy moeder was van so 'n aard dat die "strijd tussen moeder en zoon - altijd goed afloopt en altijd enige vervreemding achterlaat" (p. 149), dermate dat daar juis by Nol 'n strewe tot toenadering tot Trix ontstaan wanneer hy van sy moeder verneem dat Trix "het slechte pad (schijnt) op te gaan" (p. 146).

$\mathrm{Na}$ Cuperus se dood sien Nol vir Trix - die epiese-strukturele plaasvervanger van Cuperus - "als een slachtoffer, waarvan wist ik niet" ( $p$. 166). Hy voel op hierdie stadium nog betreklik neutraal en afstandelik teenoor haar: "ik haatte haar niet, liefhebben deed ik haar nauwelijks nog, al besefte ik, dat de foltering, die ik doorstond, de liefde was in haar opperste vorm, zoals het lichaam die ervaart" (p. 166). Hy hoor ook nou die stem van sy gewete met hom praat: "Trix loslaten - Trix loslaten Trix loslaten" (p. 167). Wat hom presies te doen staan, is hier nog nie vir hom duidelik nie, want hy spreek hier 'n behoefte uit na "een perspectief op jaren en tijden" (p. 166). Die spore van hierdie gedagtes kan teruggevind word in De toekomst der religie in die beskrywing van die (religieuse) mens as onseker, vertwyfeld en gekweld (Vestdijk, 1975:18). Waarop dit verder dui, is dat die mens volgens die mensbeskouing in De toekomst der religie nooit van sy religieuse strewe na geluk kan loskom nie; Nol is, soos alle mense, op soek na religieuse geluk wat bestempel word as duursame, suiwer geestelike geluk (Vestdijk, 1975:19).

By sy moeder se sterfbed besef Nol dat hy 'n kéúse het, want "mijn moeder leed, ik leed; maar zij kon niet weglopen, ik wel” (p. 181). Sy vroeëre egosentrisme maak nou plek vir 'n introspektiewe selfbewussyn en hy dink dat dit nie die ergste was "dat mijn moeder stierf, of niet stierf, leed of niet leed, maar dat ik leefde, nog leefde ... zo leefde" (p. 181). In die gekursiveerde "ik ... nog ... zo" is nou sy ontwakende skuldbosef opgesluit. Hy besef nou dat hy nog altyd sy verantwoordelikheid teenoor homself wou miskyk en besig was om homself te bedrieg:

... ik had een zwendelspelletje met mijzelf gespeeld daar in de universiteitstad, byna drie jaar lang. Ik had geen rekening gehouden met mijn maag en mijn darmen, ik had mijzelf uitgehold, grote 
plekken waren verdroogd, zodat mij de openbaringen waren onthouden en de gehoorzaamheid daaraan (p. 181-182).

Hy is dus besig met ' $n$ introspektiewe aanklag teen homself, hy besef die leegheid, waardeloosheid en sinloosheid van sy bestaan.

Dit is betekenisvol vir die struktuur en die visie van die verhaal dat Trix juis in die stadium van Nol se ontwikkeling wanneer hy die Sociëteit in die Tuin besoek en hom te buite gaan met drank, hom daaraan herinner dat "ieder mens verandert" (p. 184). Dit sou hom slegs twee dae (vanaf sy moeder se dood tot Trix se dood) neem om uit te vind dat sy oorgawe aan drank maar net 'n wegskram van die werklikheid is en nie die singewende daad kan vervang nie, want hy dink op die aand van sy moeder se sterwe nog: "bovendien was dit drinken altijd nog iets belangrijker dan Trix, op dit moment' (p. 185).

Geleidelik dring Nol deur tot die vir hom skokkende ontdekking van wat met Trix gebeur het. Heftig emosioneel reageer hy:

... een wereld van woede brak in mij open, en in die woede lag besloten mijn liefde voor haar, die zelf woedend was geweest van het ene jaar op het andere, oud voor haar tijd door woede, diep gewond, uiterlijk koel en schamper - o, hoe goed begreep ik haar!" (p. 213.)

Dit gaan egter hier nie soseer om die medelye van die kant van Nol nie, want hy dink aan Trix as "deze verschoppeling, met wie ik niet eens medelijden had, omdat ik meer van haar hield dan van de zon en de maan" (p. 213). Pop (1976:21) wys daarop dat medelye die bevestiging sou wees van die afstand wat daar altyd tussen hulle sou gewees het. Tog bedink Nol hom later deur te noem dat daar tóg medelye vir Trix was, asook 'n onbepaalbare angs. Later sou die gevoel van angs weer terugkeer wanneer Nol voel dat hy ongelukkig sou word, maar nie weet hoekom nie. Die gekursiveerde "Ik zou zeer ongelukkig worden" (p. 234) suggereer Nol se onsekerheid oor die toekoms. Blykbaar is daar wel 'n gevoel van toenadering van Nol teenoor Trix; tog is daar tydens hulle laaste gesprek weer die duidelike element van afstandelikheid. Nol voel dus simpatie vir Trix in plaas van empatie met haar. Sy liefde is in werklikheid nie gerig op Trix self nie, want "een huwelijk met haar (zou) een afbetalen van dankbaarheidschuld aan haar vader, mijn leermeester zijn" (p. 214) en daardeur "de mensen een lesje in goed gedrag" (p. 228). Sy doel met die huwelik is dat "W... een beetje consideratie (moet) leren krijgen met mensen als jij en je vader" (p. 228). Hy besef egter vir geen oomblik dat hierdie trotse meisie haarself tydens haar bieg aan hom uitlewer nie (Pop, 1976:22). Nol is nie in staat om met 'n enkele eg oortuigende gebaar te reageer in dié situasie nie en is hom heeltemal 
bewus daarvan: "ik had iets meer medeleven kunnen tonen, dacht ik half beschaamd, er was weer een kleine fout begaan ... Een onmetelijke rust. Haar lichaam tegen mij aan zonder beroering van mijn zinnen" (p. 215). Ook later dink hy: "Ik ben nog geen ogenblik uit mijzelf lief voor haar geweest" (p. 229). Selfs wanneer hulle mekaar hartstogtelik omhels,

... bleef ik niets anders voelen dan steeds diezelfde rust, die uit tederheid gemengd was, plechtigheid, weemoed en een staalharde, misschien wel ijskoude overtuiging, de wereld en het leven, de tijd en het verval te kunnen overwinnen door dit te zijn, dit te doen, dit op mij te nemen (p. 216).

Dit wat hy op hom wil neem, is sy poging om sy ereskuld aan Cuperus te betaal deur met Trix te trou - wat dan meteen 'n volgende belangrike stadium in Nol se karakterontwikkeling is. Die vroeëre gevoel van angssonder-objek word dus deur Nol positief verander deurdat hy hom nou rig op die beplan van daadwerklike optrede - hy wil met Trix trou. Nol se oorwinning oor homself en sy nuutgevonde vryheid is dus daarin geleë dat hy in die situasie van die driehoeksverhouding tussen homself, Cuperus-en-Trix en die gemeenskap van W... sy waardes hersien het, 'n keuse gemaak het vir die daad om sodoende sin aan die werklikheid te gee.

'n Baie belangrike faktor in Nol se poging tot singewing aan die werklikheid, wat terselfdertyd ook ' $n$ volgende fase in sy ontwikkeling toon, kom ter sprake ná Trix se dood - die tyd, die te-laat. Waar Nol nog die vorige aand selftevrede gedink het: "... zij had ontzaglijk veel geleden, zij zou zich als herboren voelen met mij" (p. 233), vind hy die volgende oggend uit dat Trix haarself vergiftig het. Duidelik het Trix se tante se onbegrypende smartklag betrekking op Nol se argelose omgaan met die tyd: "Jullie hielden toch van elkaar, Nol? Al jaren lang, dat weet ik. Ze heeft nooit naar een andere man omgekeken" (p. 243). As hy die volle verantwoordelikheid van die werklikheid ook deur die dáád sin gegee het toe hy nog die geleentheid gehad het, sou hy nie nou ook indirek aan Trix se dood skuld gehad het nie. Hy word veral bewus van spesifieke tyd:

... ik had bij haar moeten blijven ... ze had erom gevraagd, omdat ze bang was voor de ochtend! ... wat zij vroeg was alleen: waak met mij éen uur. Ik had haar minstens veertien dagen niet uit mijn ogen moeten laten gaan, geen seconde (p. 247).

Die uitdiep van die oomblik word nou van lewensbelang. Hy voel: "Maar ik heb ook schuld, want ik ben jaloers geweest" en "ik ben de grootste misdaad van mijn leven begaan" (p. 246, 247), omdat hy nie sy tyd vir 
iemand anders wou gee nie. Hy voel ook dat sy skuld verder daarin geleë is dat hy jaloers was en dit laat blyk het.

Uiteindelik dwaal Nol verbysterd in die stad rond, sonder rigting, sonder dat hy weet wat hom verder te doen staan: "Mijn radeloosheid, mijn volstrekte wanhoop kon ik mijzelf bekennen, maar ik kon er niet naar handelen, ik kon niet door de straatstenen zinken, of in de lucht oplossen" (p. 252). Dié gedagte word nie slegs deur Nol as hoofkarakter uitgespreek omdat dit fisies onmoontlik is nie, maar ook omdat die visie hier impliseer dat dit psigies onmoontlik is om doelloos maar tog sinvol te bestaan. Sy moraliteit sal dus daarvan afhang of hy opnuut 'n keuse sal kan maak, sodat hy weer kan stréwe.

Nadat die aanvanklike heftige skok afgeneem het, dink hy aan die rigting van hier af verder:

Dit was een levensdoel: niet verheven, niet tot navolging wekkend, maar toch iets ernstigs en sinrijks en de enige kans misschien om op den duur te leren begrijpen, niet waarom ... maar dat Trix dood was gegaan (p. 253).

Sy weerkaatsing in 'n winkelvenster lyk vir hom soos dié van "een zwerver, die kranig voortstapt om zijn enige plicht éen maal 's jaars te gaan vervullen" (p. 254). As hy dankbaarheidskuld teenoor Cuperus gehad het wat hy wou betaal deur met Trix te trou, het hy nou ook des te meer skuld wat hy teenoor die nagedagtenis van Trix moet vereffen - sy indirekte skuld met betrekking tot haar dood. Skuld as sodanig word dus baie prominent in die persoon van Nol uitgebeeld. Wat aanvanklik maar dankbaarheidskuld was, word nou morele skuld, omdat hy indirek aandadig was aan Trix se dood. So ontstaan daar deur die karakterisering van Nol 'n derde dimensie van skuld, naamlik sy lewenslange skuld om van oomblik tot oomblik sy skuld teenoor dié twee mense terug te betaal deur bewustelik sinvol te leef. Wanneer Nol aan die einde van die verhaal vir Caspers as een van die verteenwoordigers van die inwoners van W... van indirekte betrokkenheid by Trix se dood wil beskuldig met die woorde "in uw plaats zou ik me eerder een beetje schuldig voelen" (p. 256), slaan hierdie beskuldigings direk op homself terug. As gevolg van sy skuld van die verlede, sal Nol sinvol moet betaal met die morele dáád; deur van oomblik tot oomblik "voort te leven van seconde op seconde" (p. 261), want "er was een prijs te betalen, een waarborg te geven, het bewijs te leveren voor wat mijn hart bond en gebonden had" (p. 271). Die keuse wat hy maak, is om almal te wil besoek wat volgens hom aandadig was aan die stigma wat kleef aan die nagedagtenis van Cuperus en Trix. 
Die geslaagde uitbeelding van die ontwikkeling van Nol as hoofkarakter hang daarmee saam dat daar 'n geloofwaardige oorgang is van die kinderjare na volwassewording. Daar is 'n verband te lê, alhoewel nie baie prominent nie, tussen jeug en angs, waarin 'n geleentheid geskep word om die angs, deur Nol ervaar as gewetensangs, te deurgrond: hoe sal hy te werk gaan om die gemeenskap van W... te oortuig van hulle aandeel in Cuperus en Trix se innerlike lyding? (Alhoewel angs gewoonlik beskou word as 'n gevoel waarby daar nie 'n omlynde, identifiseerbare, bepaalbare objek as oorsaak is nie, terwyl vrees behels dat daar wel 'n duidelik identifiseerbare objek is, is dit duidelik dat Vestdijk onder angs verstaan dat daar in sekere kontekste wel 'n objek as oorsaak van die angs kan bestaan.) De Jonge (1983:25) wys daarop dat bestaansangs steeds betrekking het op die medemens, omdat dit ontstaan uit die situasie van skuldig-wees; hy vervolg dat angs eers dán vat kry op die mens wanneer hy byvoorbeeld die herhaling van sy misdaad vermoed of as hy tot die besef kom dat hy nie met die daad vir sy skuld kan betaal nie. By Nol bestaan daar uiteindelik die behoefte aan die daad as middel om die angs te bestry en te besweer; hy wil die stad, die (verhaal-)wêreld ingaan en ander op hulle aandeel in die noodlottige gebeure wys. Dié gerigtheid by Nol kan egter nie gesien word as 'n altruïstiese gerigtheid op alle lede van die samelewing nie; vanuit sy individualiteit wil hy retrogressief en progressief optree téén diegene wat ander se lewens veronaangenaam.

Van 'n positiewe verhouding met God is daar nie sprake by Nol nie; in die verbeelde dialoog met Caspers sê hy: "ik geloof in God, maar Hij laat mij in de steek" (p. 267), waaraan Caspers toevoeg: "als ik in God geloofde, zou ik blindelings op Hem vertrouwen, in éen richting als het ware" (p. 267). Maar omdat Caspers 'n skyngelowige is, word hierdie Godsbeskouing gerelativeer tot die beeld van 'n God wat nie in kommunikasie staan met die mens nie. Omdat God die mens volgens hierdie visie in die steek laat, vervaag sy beeld as Singewer van die mens se bestaan en word die verantwoordelikheid van singewing op die mens self geplaas - in die roman dus op Nol as draer van die visie.

Daar is aanduidings dat daar 'n selfontmoeting moet plaasvind. Hiervan sê Cornets-de Groot (1975:65) dat dit bereik kan word nie deur met die self saam te val nie, maar deur afstand te neem van die self: “... door het vermogen zichzelf te kunnen zien, als door de ogen van een vreemde. Door zelfkritiek". Dit sluit aan by die Vestdijk se siening van die mistiek as suiweringsproses. Dié idee moet egter nie verwar word met wat Vestdijk (1975:239) beskou as 'n onttrekking van die "ek" van die "ander" in 'n poging om vryheid te ervaar nie. Nol voel gedurende sy studentetyd dat hy, om homself te beskerm teen die wyse waarop hy hom kan ontstel, hom geestelik wil isoleer: "Want er was ook een wijd, ja groot- 
scheeps gevoel in mij dat mij van alle mensen en dingen verwijderde, vrij maakte" (p. 147). Na sy eindeksamen ontspan hy saam met sy vader en Chris:

... in de vacantie maakte ik met mijn vader en Chris een reis door Duitsland, met de Beierse Alpen als doelwit, dat door de beide anderen niet werd bereikt. ... In hun gezelschap had ik mij geen minuut verveeld, maar toen ik het sneeuwgebergte voor mijzelf alleen had, moest ik mijzelf wel afvragen, of deze ingenomenheid met mensen, die mij zo weinig te zeggen hadden, niet een teken kon zijn van naderende verkilling, sluipende verburgerlijking (p. 176).

Om met ander oor die weg te kom, beteken volgens die visie van die roman nie om die individualiteit totaal prys te gee nie. Later sou hy insien - as spreekbuis van die geponeerde werklikheidsbeskouing in De toekomst der religie - dat die vryheid nie geleë is in onttrekking van die ander in individualistiese isolasie nie, maar dat juis in die selfgeïntegreerde gerigtheid op ander sin gegee word aan die bestaan; vryheid is dan die gevolg van die aanvaarding van die uitdagings van die lewenswerklikheid (Vestdijk, 1975:239).

Die ontwikkeling wat daar by Nol plaasvind, kom daarop neer dat hy 'n ander soort introspeksie doen (van beóéfen is nie hier sprake nie) as voorheen. Hy is besig om te groei in die rigting van die mistiek-introspektiewe tipe, maar met 'n neiging ook na die sosiale tipe. Sy denke en optrede is implisiete verwysings na die oorgange en oorvleuelings tussen persoonlikheidstipes soos dit in De toekomst der religie bespreek word (Vestdijk, 1975:13, 249). Om te ontwikkel na 'n individu wat steeds meer geïntegreerd raak, wil hy, om die duursame geestelike geluk deelagtig te word, hom ook op ander rig - 'n aspek van die werklikheidsbeskouing van De toekomst der religie waarin dit duidelik gestel word dat die volmaakte geluk nóg in die self, nóg in die ander, maar in oorvleueling met mekaar nagestreef kan word (Vestdijk, 1975:19, 134). Nol is nou 'n karakter wat na suiwerende introspeksie streef en wat met die "ander" in kontak wil kom sodat hy hulle kan bewus maak van die geweld wat met die tong gepleeg kan word. Die mate waarin hy gedesintegreerd voel teen die einde van die roman, is bloot 'n aanduiding dat hy nog nie sy ideaal volledig bereik het nie; hy is nog maar ingestel daarop. Dié gevolgtrekkings kan gemaak word na aanleiding van die bespreking van die geïntegreerde en gedesintegreerde tipes; die geïntegreerde tipe waaraan Vestdijk in De toekomst der religie voorkeur gee, is 'n oorvleueling van die mistiek-introspektiewe en die sosiale tipes (Vestdijk, 1975:70-71, 247-248).

In hierdie roman is dit ook waar wat Vestdijk (1976:50) elders sê: 
Men is trouw zolang men lief heeft en het eerste is een gevolg van het tweede. Intussen blijven hiermee de veelvuldig voorkomende gevallen onverklaard, waarin de trouw de liefde overleeft - gevallen, die uiteraard het meest tot onze verbeelding spreken, omdat zij een zuiverder oordeel toelaten over der trouw als sodanig.

\section{Die doel nooit finaal bereik nie}

Dit het dus duidelik geword dat die visie in De koperen tuin wat in in hoë mate deur die hoofkarakter Nol gedra word, 'n uitbreiding is van aspekte van die werklikheidsbeskouing in De toekomst der religie, 'n variasie van die eksistensialisme van die twintigste-eeuse Europa. Nol as verhaalkarakter is die werklikheidsgebonde, eksisterende mens wat uit sy afstandelike houding teenoor sy medemens wakker geskud moet word. Dit word bewerkstellig deur die dood van die twee persone wat hom die naaste aan die hart gelê het, naamlik Cuperus en Trix, sodat hy sy waardes kan hersien. In die situasie waarin by hom bevind, naamlik as tussenganger in die verhouding tussen die onverdraagsame gemeenskap en die enkeling (eers Cuperus en daarna Trix), moet hy sin gee aan sy eie bestaan deur homself te verwerklik deur sy verhouding met en tot die ander. Nol ervaar sy angs en skuldig-wees in die roep van sy gewete - hy moet keuses maak. Hy voel verantwoordelik om sy dankbaarheidskuld teenoor Cuperus te betaal deur met Trix te trou, maar ook om later eweneens teenoor die gestorwe Trix van oomblik tot oomblik die prys te betaal vir die vryheid van sy gewete. Dié vryheid wil hy verwerf deur die daad van bewusmaak van die gemeenskap van W... van hulle onverdraagsaamheid en hulle aandeel aan die leed en lot van ander. Die swaartepunt van die sin van Nol se bestaan lê dus in die ontmoeting met ander ter wille van die verwerkliking van die self.

Op strukturele vlak is dit betekenisvol vir die visie van die roman dat Nol karakterontwikkeling móét toon, maar karakterontwikkeling wat, alhoewel die ruimtebeelding 'n sirkelstruktuur toon deur die essensiële verhaalgebeure wat begin en eindig in die Tuin, eindig in 'n oop slot, omdat Nol van almal wat hy hom voorgeneem het om te gaan besoek, nog net by Caspers uitgekom het. Op dié wyse dra ook die epies-tegniese van die roman by tot die werklikheidsvisie, naamlik dat die mens onaf, onvoltooid is, in elke situasie steeds 'n nuwe keuse moet maak en deur die uitdiep van elke oomblik steeds moet wórd.

Daarmee is dit ook duidelik dat die werklikheidsbeskouing van die reële outeur Simon Vestdijk, soos uiteengesit in De toekomst der religie, en die visie van die implisiete outeur en visie van hoofkarakter in De koperen tuin dieselfde is. Die geponeerde werklikheidsbeskouing van De toekomst der religie word deur middel van intertekstuele objektivering en 
verdieping vergestalt in die hoofkarakter as belangrikste draer van die werklikheidsvisie van die roman De koperen tuin.

\section{Bibliografie}

Beets, N. 1977a. Psychologie van de angst, de verveling en de vriendschap in Sint Sebastiaan en Surrogaten voor Murk Tuinstra. Vestdijk Kroniek, 17:2-19, Sept.

Beets, N. 1977b. Annie Vermeer, Dirk Touraine en Jules Salomons. Vestdijk Kroniek, 18:19-34, Des.

Cornets de Groot, R.A. 1972. Vestdijk op de weegschaal. Leiden : Sijthoff.

De Jonge, H. 1983. Geheime genootschappen en gluurders: angst en angstbestrijding bij Vestdijk. Kroniek, 40:16-36, Sept.

Faber, J. 1980. Over de Engelse vertaling. Vestdijk Kroniek, 30:11-13, Des.

Minnaar, L.C. 1982. Wêreld en waarde: Magersfontein, o Magersfontein in oënskou. Potchefstroom : PU vir CHO. (Wetenskaplike bydraes van die PU vir $\mathrm{CHO}$. Reeks J, Potchefstroomse Studies in Christelike Wetenskap, J2. Monografieë; no. 2.)

Musarra, U. 1983. Narcissus en zijn spiegelbeeld. Assen : Van Corcum.

Oversteegen, J.J. 1974. Elf maal de koperen tuin: kritische reakties bij de verschijning van een nieuwe Vestdijk. Vestdijk Kroniek, 5:55-63, Sept.

Pop, J. 1976. Over De koperen tuin van Simon Vestdijk: synthese. Amsterdam : Wetenschappelijke Uitgeverij.

Schrijversnet. 2001. Trefpunt voor Nederlandstalige literatuur. http://www/schrijversnet.nl/vestdijk.htm [Datum van gebruik: 5 Februarie 2001].

Steenberg, D.H. 1975. Sestigerproblematiek: aanleiding tot 'n Christelike literatuurbeskouing en kritiek. Potchefstroom : Pro Rege.

Van der Westhuizen, E.S. 1990. De toekomst der religie en De koperen tuin van Simon Vestdijk: 'n intertekstuele ondersoek. Potchefstroom: PU vir CHO. (M.A.verhandeling.)

Van Hattum, M. 1977. De koperen tuin: van paradijs tot Golgotha. Vestdijk Kroniek, 125:35-41, Mrt.

Vestdijk, S. 1950. De koperen tuin. Rotterdam : Nijgh \& Van Ditmar.

Vestdijk, S. 1958. De Poolse ruiter. Den Haag : Bakker.

Vestdijk, S. 1975 (1947). De toekomst der religie. Amsterdam : Meulenhoff.

Vestdijk, S. 1976. Essays in duodecimo. Amsterdam : Meulenhoff.

\section{Kernbegrippe:}

lewensbeskouing

lewensvisie

Simon Vestdijk: De koperen tuin, De toekomst der religie

\section{Key concepts:}

life and world view

Simon Vestdijk: De koperen tuin (The garden where the brass band played), De toekomst der religie (The future of religion)

vision of life 